\title{
Strangers and Migrants in the Making of African Societies: A Conceptual and Historical Review
}

\author{
Robin Cohen ${ }^{1}$ (D)
}

Received: 4 September 2017/Accepted: 24 October 2017/Published online: 8 November 2017

(C) The Author(s) 2017. This article is an open access publication

\begin{abstract}
At the extremes, there are two forms of engagement with strangers- the anthropophagic, where outsiders are swallowed and digested, and the anthropoemic, where aliens are discarded, institutionalized, incarcerated or expelled. Using this dyad as a conceptual tool, I examine seven patterns of inclusion/exclusion in African societies, covering early agricultural societies, the formation of kingdoms, societies formed by refugees, strangers in pre-colonial cities, migrants in colonial cities, ethnic expulsions as a result of modern state formation and migrants in contemporary global cities. The aim of the article, based on an extensive review of secondary literature, is to add historical, comparative and typological elements to an often inadequate sociological and anthropological sensibility concerning hosts and strangers.
\end{abstract}

Keywords Strangers · Migrants · African state formation · Expulsions · African history

Thinking of the dyad inclusion/exclusion recalls a graphic passage in Levi-Strauss (1995: 297-8) contrasting cannibalism with anthropemy:

If we studied societies from the outside, it would be tempting to distinguish two contrasting types; those which practise cannibalism ... that is, which regard the absorption of certain individuals possessing dangerous powers as the only means of neutralising those powers and even of turning them to advantage ... and those which, like our own society, adopt what might be called the practice of anthropemy (from the Greek emein, to vomit) ... which consists of ejecting dangerous individuals from the social body.

Robin Cohen

robin.cohen@kellogg.ox.ac.uk

1 Kellogg College, University of Oxford, 62 Banbury Rd, Oxford OX2 6PN, UK 
As Jock Young (1999: 56-95) argues, this creates two forms of society-the anthropophagic (characteristic of what Lévi-Strauss insists on calling 'primitive society') where outsiders are swallowed and digested, and the anthropoemic, where aliens are discarded, institutionalized, incarcerated or expelled. It is not hard to discern that Lévi-Strauss prefers the former response, which he depicts as more human and more natural-and suggests it is the common response of the Amazonian people he so admired. While I am not likely to be on my own in my discomfort with his word 'primitive', nonetheless I think we have a basic and elegant dyad which can serve our purposes well, namely a contrast between swallowing and digesting strangers on the one hand and vomiting them out on the other.

Perhaps it is not too great a generalization to say that many early African societies were anthropophagic, seeing strangers as non-threatening guests and at least capable of being digested in the social body over time. Clearly such a generalization will not sustain too much scrutiny over time and other variations have also emerged. In all, I propose seven forms of society each with a distinctive pattern of social inclusion/exclusion. Each is discussed in turn:

1. Agricultural societies with a sufficient degree of land to allow generous practices of usufruct, allocated collectively (in acephalous societies) or more centrally (in more hierarchical ones).

2. The formation of kingdoms involving captives and slaves who were joined to the body politic by force.

3. New societies formed by refugees fleeing from traumatic exogenous natural disasters-like floods or extensive droughts, human-made political calamities like Arab and European slavery, or the series of events loosely described as the Mfecane.

4. Strangers, often traders, entering pre-colonial cities and forming (or being enclosed in) sabon garuruwa (explained below), such as those found in Nigeria.

5. Migrants arriving in colonial cities, factories and mines as labour migrants, and often being part of organized oscillating systems of mobility regulated by the state or employers.

6. The forcible expulsion of unwanted ethnic, national or religious minorities as elites in post-colonial states seek a more homogenous national identity.

7. Migrants entering large, fragmented, global cities, the exemplary cases being Lagos, Nairobi and Johannesburg.

\section{Early Agricultural Societies}

One should not get trapped into a mythology of a timeless, universal African communalism, free of class antagonisms or gender oppression, acting benignly in the interests of the community. ${ }^{1}$ There is just enough in this characterization to be

\footnotetext{
1 In an early paper on class in Africa (Cohen 1972b) I examined the limited factual basis of these ideological claims.
} 
recognizable to many rural Africans and, more pertinently, enough for Nyerere (1988) to use the idea of Ujamaa (family-hood) as the basis for the construction of a post-colonial socialism. The similar idea of Harambee (pulling together) informed a very brief flirtation with socialist ideas in Kenya. Perhaps one would be foolish to dismiss these anthropophagic tendencies too quickly. The osmotic acceptance of refugees and other border crossers into Zambia provides one contemporary example (Bakewell 2000) as does, in general, the African Union's relatively open-minded legal protocols on the treatment of refugees. Similar notions are visible in Swahili hospitality proverbs, which imposed mutual obligations on guests and hosts. Here, for your delectation are a few collected by the Center of African Studies at the University of Illinois. $^{2}$

Heri yako heri yangu.

'Your happiness is my happiness', said to a guest.

Karibu mgeni, lakini humwekei macho.

'Invite the stranger but do not scrutinize him'

Kazi haina ugeni.

'Work knows no guest'. Explanation: when a guest arrives, the guest gets time to be entertained and to rest. When that period is over, and the host resumes his work, which even the guest can do, the guest joins in without hesitation.

Kula ni faradhi ya kila mtu.

'Eating is the right of everybody. Nobody must ever be refused food'.

Mgeni hachomi chaza mtaani akanuka.

'A stranger does not roast an oyster in a village and then get accused of smelling of it'. Explanation: a stranger should be excused for strange ways.

Mgeni hachukui nyumba.

'A guest does not take over the house'.

Tabasamu hushibisha.

'A smile satisfies hunger'. Explanation: even if there is little food, if the host gives it with an open and happy heart, the guest will be satisfied'.

These proverbs are all rather charming and attest to deep traditions of hospitality in East Africa. However, it would be a romantic invention to suggest that these conventions were universally accepted or acted upon. The more plausible generalization is that early societies were formed by contiguous but barely-related kin, clan and lineage groups, which joined together through migration, myths of a common origin or early forms of clientalism. There are many accounts of such a pattern. Take, for example Cohen (1972a: 70-123) account of 'Kintu', the legendary founding figure of Busuga (Uganda). He was said to have arrived with the banana, with millet and with cattle-the latter association signalling the displacement of small-scale agriculture with pastoralism. He is connected, mythologically, to many clans. He is God, the son of God (perhaps this indicates this legend is a postChristian invention), the father of all people, the distributor of totems and the founder of the emerging kingdom (Cohen 1972a: 71). The settlement of Busuga associated with Kintu involved the inward migration of no fewer than fifteen clans,

\footnotetext{
${ }^{2}$ The full list of 37 proverbs is available at http://swahiliproverbs.afrst.illinois.edu/hospitality.html.
} 
all of whom claimed filiation, clientage to, or descent from, Kintu (Cohen 1972a: 85 ). In short, inventing a common ancestor, moreover one of such status and power, helped to bind stranger to stranger in the formation of a reasonably coherent society.

More speculatively, this process was limited by the amount of rain and river-fed arable land available. Land allocation was by usufruct-allowing families, clans and kin groups the right to continuous use, but not permanent ownership, let alone absentee ownership or bequeathable title. So long as there was enough land, all was well. As cattle-owning pastoralism became dominant, land available for usufruct diminished, thus enhancing the likelihood of conflict. Transhumance also probably eroded credible claims to a common ancestry-thus making social formation/social inclusion more difficult.

\section{Formation of Kingdoms}

In contrast to the rather chaotic and more egalitarian patterns in small-scale agricultural societies, strangers in large states were often captives (generally women or children) and slaves who were welded to the body politic by coercion. George Balandier (1968: 11) suggests that in the sixteenth, seventeenth and eighteenth centuries the kingdom of the Kongo witnessed 'a massive predominance of villagers of slave status in certain regions: this was the result of a gradual accumulation by an aristocracy which originally possessed only the advantage of freedom'. West African kingdoms such as Mallel (Mali), Ghana, Songhai, Kawkaw, Kanem, Sila, Daw, Mossi and Dagomba exhibited similar patterns of subordinating tribute people and slaves (Fage 1969: 1-46). Although many of these empires endured for decades, occasionally centuries, they were, in turn, vulnerable to collapse and takeover, the subordination of Ghana by the Almoravids in 1076 being a case in point (Fage 1969: 19).

To these empires, strangers were essential in building up tribute (generating what Marx called primitive accumulation), fostering long-distance trade and raising defensive or offensive armies. The unifying force of Islam in the Sudanese/West African kingdoms and the Orthodox Tewahedo Church in Ethiopia provided the ideological cement binding subjects and slaves to their rulers.

\section{Refugee State Formation and Displacement}

Both the processes described above (pressure on the land and the formation of aggressive empires) created mobile, dispossessed, transient populations that were often forced to regroup in less hospitable habitats - in the dry lands of the savannah, under forest cover and in mountain fortresses. The displaced populations fleeing from Shaka's Zulu kingdom provide a familiar example. New ethnicities were formed as waves of smaller clans escaped the reach of the Zulu impis and united for self-defence, the Matabele and Mfengu being cases in point. As Zulu military tactics and the murderous use of the stabbing spear in hand-to-hand combat spread to other 
groups (such as the Ngoni in East Africa), further displacements arose (OmerCooper 1978).

Refugee state formation in what is now called the kingdom of Lesotho initiated by its renowned chief, Moshoeshoe, is interestingly described by a Swazi commoner (Jingoes 1975: 15), who become a legal assistant and interpreter to the Sotho chiefs:

Chief Moshoeshoe, the founder the Basotho nation, was a strange and wise man. I have been told that whenever he learned that people who were strangers had settled near his stronghold on Thaba Bosui, he would commission some of his own people to visit these strangers. He would instruct his people to observe and learn the ways and customs of the strangers. He warned them not to do away with their own customs or traditions, however, but to bring him word about the new things they had learned. Then he himself, with his people, would decide which of the new customs were good and should be adopted, and which should be rejected.

Of course this account is framed in pre-sociological language and alludes to what we might now describe as acculturation, state-led integration, or perhaps creolization. It is testament to the success of this process that a contemporary Lesotho social anthropologist (Modo 1994) can refer to Lesotho as a nation-state 'made up of almost a homogenous group'. As Modo suggests, this does not prevent conflict with competitors falling back on clan membership, political manoeuvring or religious difference, while his colleague Khalanyane (2012) adds that there are other forms of exclusion and usurpation in Lesotho including 'credentialism' (insisting on qualifications, even where not appropriate) and social closure through the privileging of certain families. 'The family name is also an important exclusionary strategy in Lesotho. If a person is not a Molapo, Letsie, Mohale or from the royalty, his or her chances of getting an essential service, employment or even being given a hearing are 'normally' near zero on any scale' (Khalanyane 2012: 229).

Whatever the force of these interventions, Lesotho can be regarded as a relatively benign example of refugee state formation. Life was much more challenging elsewhere. Arab-led slavery in East Africa and the European transatlantic slave trade caused massive disruption. About 11 million Africans were transported across the Atlantic; even larger numbers were affected by the Arab trade (with estimates of between 11 and 15 million being common). Another extraordinary case is the series of events loosely described at the Mfecane ('the scattering'). This expression refers to the period 1826-36 when Mzilikazi, the Matabele king, ordered mass killings, affecting one to two million people, in the process of establishing the Ndebele polity. Until 1988, the conventional historical explanation for these events (ignoring African oral traditions, which told a more complex story) was that the Mfecane was a tragic consequence of Zulu expansion. In a provocative article Julian Cobbing (1988) denounced this interpretation as a self-serving, pro-apartheid, white version of history (the version that claimed that blacks were continually engaged in tribal warfare and white settlement was a benign force). Instead, he pointed the causal finger firmly at the emerging colonial order and its search for forced labour, in 
particular the demands of two groups, Portuguese slavers and colonists from the Eastern Cape. ${ }^{3}$

At any event, the resulting displacement, war and famine allowed much easier access to the land by the Afrikaners trekking into the interior, and the subsequent formation of the Transvaal state. Also sometimes linked to the Mfecane was the slaughter of livestock by the Tembu in 1857 who, gripped by the visions of a young girl, destroyed their own livelihood and became impoverished migrant workers.

Perhaps part of this pattern, but probably meriting separate discussion on its own, is the development of mixed heritage communities, for example those in the northern Cape, which blended European, African, Khoi and San peoples. Selfdefinitions of this group include 'Bastaards', 'Basters', 'Korana', 'Oorlam' and 'Griqua', though the last was legitimated by the London Missionary Society and is the most polite. Under the formidable military and political leadership of the Koks family, the Griqua were able to maintain considerable independence from Bantu, Boer and Briton for many years. Given my focus on social inclusion, other mixed heritage communities worth studying are the Afro-Shirazis of Zanzibar, the Malagasies of Madagascar (many of whom were Austronesian settlers from Borneo), and the Creole populations of contiguous islands and enclaves, such as Mauritius, the Seychelles, the Comoros, St Helena and Cape Verde. (The case of the Hausa-Fulani is briefly discussed below.)

\section{Strangers in Stranger Quarters}

There are many examples of this pattern of inclusion/exclusion, but the most prominent are the sabon garuruwa ('strangers' quarters'. Sing. sabon gari) in northern Nigeria. John Paden's (1973) comprehensive study of Kano provides useful information. He points out that the Kano empire was itself ethnically mixed-about one-third Fulani and two-thirds Hausa. Many of the Fulani clans were jihadists and there was some tension, but the relationship was 'transformed during the nineteenth century into a pluralistic relationship based on division of labour [and] mutual economic interdependence' (Paden 1973: 22, 23). The HausaFulani are now generally regarded as a single ethnic group. Not so those peopleIbo, Ibibio, Edo, Yoruba and Middle Belt people-who live in the sabon garuruwa. Initially, Kano's sabon gari housed Christian semi-skilled southerners, often railway workers, working for the colonial administration. Ibos tended to be Roman Catholic, while Yoruba were often Protestants or members of the Aladura Church. The religious fault line between the Hausa-Fulani and other ethnicities was legally reinforced by the Emir's prohibition in 1912 forbidding non-Muslims to live within Kano's city walls. Paden (1973: 317) characterizes the outcome as follows:

By 1965 the Kano urban area approximated the classic Furnivall model of a plural society. The three major communities - northern Nigerian (Hausa and Fulani), southern Nigerian (Ibo and Yoruba) and expatriate (British and

\footnotetext{
3 Subsequent research has somewhat modified the Cobbing thesis. While essentially intact, it remains the subject of fierce controversy (see Hamilton 1995).
} 
Lebanese)-were linked together through the central commercial zone but were not integrated in social and political spheres. ... Although in many ways the expatriate community commercially dominated the urban area, the economic competition between the northern and southern communities in Kano is more relevant to the process of community formation. The three major types of competition were markets, employment and land.

The reference to Furnivall is to his famous characterization of the Europeans, Chinese, Indians and indigenous people in Burma, namely that: 'they mix but do not combine. Each group holds by its own religion, its own culture and language, its own ideas and ways. As individuals they meet, but only in the market-place, in buying and selling' (Furnivall 1948: 304). Certainly, the social isolation and geographical separation of those in the sabon garuruwa made them easily identifiable in moments of economic and political crisis. Riots against the southerners became a sickening feature of Kano life-in 1953, in the prelude to the 1967 civil war and again in 1981. The radical Islamic movement, the Boko Haram, has been responsible for about 15,000 deaths between 2001 and 2016, many of them in the sabon garuruwa (Uhrmacher and Sheridan 2016).

Though Paden evokes Furnivall's work on Burma, perhaps a better comparison is to ghettos, first established for the Jews in Venice, who were regarded as aliens unable to live alongside Christians. (Mellahs in Morocco had the same function.) Underlying notions of pollution and threat informed the development of ghettos. The Nazis corralled Jews and Roma ('Gypsies') into ghettos to control and eventually eliminate them. Nowadays the term 'ghetto' is used to refer more loosely to alienated urban populations who live in poor areas, for example African Americans in parts of Chicago. Although this is something of a stretch, the Natives (Urban Areas) Act of 1923 in South Africa bears some resemblances to the sabon garuruwa of northern Nigeria and to the idea of a ghetto. It is also relevant to note that post-1948 apartheid legislation built on earlier patterns of spatial segregation. ${ }^{4}$

\section{Migrants in Colonial Cities and Mines}

By far the most important theories on social inclusion/exclusion in Africa arise from anthropological and sociological discussions of the migration to the African cities in general and to the mines of southern Africa in particular. There are dozens of significant studies, thought the ones I have selected below are determined by their originality and influence on wider social science issues.

Mainstream social scientists were particularly influenced by two leading questions: (1) would Africans migrating to the emerging industrial and administrative cities become detribalized and therefore open to anti-colonial struggles? (2) Would Africans entering the workplace become proletarianized and perhaps open

\footnotetext{
4 The association with colonial models of social segregation was most evident in Natal, the heartland of British administration where, in the 1920s, the essential elements of urban apartheid were constructed, over a quarter of a century before apartheid ideology was formally articulated. Thus, the conventional idea that apartheid was a wholly Afrikaner invention is erroneous (see Cohen 1986: 26-30).
} 
to trade union influences? Both questions were addressed by scholars on the right and the left (obviously with different motivation and intent) and were also the subjects of official investigations. Two of the most important official reports were Lord Hailey's (1938) African survey and J. Merle Davis's Modern industry and the African (1933). Both are formidable works of investigation; the former is 1662 pages long and took a group of researchers five years to complete. In each case the 'integration' feared was to radical ideas, which could threaten to derail colonial plans for slow reform (known as 'welfare colonialism') and gradual decolonization.

More conventional scholarship generated a wealth of complex answers to these questions. Abner Cohen (2004: 1) argued that Hausas in Ibadan (a southern Nigeria city) manifested not detribalization, but retribalization, a phenomenon, he suggested:

is the result, not of ethnic groupings disengaging themselves from one another, but of increasing interaction between them. ... It is the outcome not of conservatism, but of a dynamic socio-cultural change which is brought about by new cleavages and new alignments of power. It is a process by which a group from one ethnic category ... manipulate[s] some customs, values, myths, symbols and ceremonials from their cultural traditions to articulate an informal political organization which it used in a struggle [for power and privilege].

Looking at the Xhosa in East London, Philip Mayer (1961) suggested that rural-born Xhosa were able to continue contact with their families and kin, despite long periods in the city. They were therefore, in that now hackneyed sexist phrase, "men of two worlds'. Such an observation would not these days be particularly noteworthy. However, his central finding was more remarkable, namely that the Xhosa split into two groups, with very different predispositions and predilections. The 'Red Xhosa' were traditionalist, conservative and valued indigenous ways, while the 'School Xhosa' were products of the missionary schools and valorized Christianity, literacy and other Western ways. Here, however, is the counter-intuitive finding-the syndromes observed did not depend on levels of rurality or urbanity. One could be Westernized and 'progressive' in the countryside and 'encapsulated' and practice backward-looking ways in the town.

Such sophisticated observations were to form the warp and woof of the studies on urbanization emanating from the Rhodes Livingstone Institute (RLI), founded in 1938 under the initial directorship of Godfrey Wilson. Merely doing the roll call of key anthropologists and sociologists at the RLI provides testament to its massive influence:

- Gluckman (1963), its next director, highlighted the repressive aspects of colonialism, providing a fertile combination of structural-functionalism with conflict theory. He left Zambia to found the Manchester School of Anthropology.

- Ronald Frankenberg help to redefine the field of community studies, particularly with his work on health in Zambian slums and his classic study of a Welsh border village (Frankenberg 1957). 
- Kapferer (1972) worked on 'strategy and transaction' (essentially network theory) in a Zambian factory.

- Epstein (1958) followed workers as they moved between two transnational 'social fields' —on the Copperbelt and in the rural areas, successfully negotiating between their identities both as workers and peasants. He also anticipated contemporary work on transnationalism and social remittances.

- Barth (1969), a student of Gluckman, worked on his subtle theory of boundary markers in ethnicity. His book on ethnic boundaries has been widely deployed across the social sciences and extensively cited.

- Turner (1968) developed his ideas of liminality where for certain periods or in certain circumstances social hierarchies and traditions could dissolve, allowing new institutions and customs to evolve. This idea of jerky and contingent processes (rather than slow evolutionary change) provides an excellent way of understanding some aspects of inclusion/exclusion.

There are others who could be on this list, but probably none so important for present purposes as Mitchell $(1969,1974)$ who developed Gluckman's ideas and further institutionalized the Manchester School of Anthropology, spreading its influence later to Oxford. It would not be too much of a stretch, indeed, to argue that the Manchester School of Anthropology was the RLI transported to less sunny climes. I mention Clyde Mitchell particularly as he was so crucial an influence in two zones of enquiry-situational analysis (where he drew on earlier work in the 1950s) and social networks theory (where he made a number of important interventions). ${ }^{5}$

While some of the RLI anthropologists worked on question of labour, including migrant labour, as I indicated their main focus was on the urban question, framed in terms of detribalization, retribalization, tradition, modernity, and the recognition of complex, alternating 'social fields'. The direct attention to labour was addressed a few years later by others, more diverse organizationally, and mostly anchored in sociology, social history, political science and radical political economy, rather than in anthropology. The sub-themes considered were the political reach of the organized working class, class formation, the 'labour aristocracy' debate, the character of labour protest and whether an emerging working class consciousness could trump prior ethnic/racial affiliations. Again, here is a roll call of some of the scholars involved in the 1970 s and $1980 \mathrm{~s}^{6}$ :

- Sandbrook (1975) wrote on Proletarians and African capitalism in Kenya, while Robin Cohen (1974) undertook a parallel study on Nigeria, titled Labour and politics in Nigeria.

- Richard Sandbrook and Robin Cohen collaborated on a landmark conference in Toronto drawing together all major scholars on African labour issues. Published as The development of an African working class: studies in class formation and

\footnotetext{
5 Steve Vertovec acknowledges him as his mentor, and co-edited a festschrift for Mitchell with Ali Rogers. Ali Rogers, Steve Vertovec and I founded the journal Global Networks in 2000, partly in recognition of Mitchell's contributions.

${ }^{6}$ I was part of this group of scholars-so apologies for the self-referencing.
} 
action (1975), the book was explicitly influenced by the English social historian, Edward Thompson, and drew also on Marxist and social democratic theory.

- The 'labour aristocracy debate' was an African take on the embourgeoisement thesis, which suggested that the working class had been incorporated into the ranks of the relatively privileged (that is the integrated or socially included) and therefore was no longer a suitable agent for revolutionary activity. The particularly African slant on this derived from a debate with Fanonist theory, which focused on the lumpenproletariat (the urban marginalized) as the true bearers of the revolution.

- Most of this group grew increasingly sceptical that class struggle could be usefully furthered through open confrontations between organized labour and state/employers and some focused instead on localized, hidden forms of resistance (including workplace sabotage). The classic work in this genre was Charles Van Onselen's Chibaro (1980) on African mine labour in Southern Rhodesia. Although a work of history, it proved helpful in understanding contemporary patterns of social inclusion/exclusion in factories and mines.

- Research on African workers also crucially addressed the obvious Marxist question of whether their experience as workers would allow them to express their social identities in class terms (or more in class terms) than in terms of their ethnic or racial background. In the context of South Africa, this question was posed directly by the Communist Party. Could black and white workers unite, as the party's orthodoxy suggested? The most sophisticated response to this question was Eddie Webster's Cast in a racial mould (1985) which, using Braverman's (1974) influential work on the labour process, showed how racial structures were produced and reproduced by the segmentation of work (and only occasionally challenged by wider appeals). White unions in South Africa, and the workers they represented, were therefore drawn into the reproduction of the social relations of production.

\section{Nationalism and the Anthropoemic (Vomiting Out) Moment}

Elites, fanning the flames of popular sentiment, often espouse strong nationalist sentiments at the moment of state formation - this is a common feature marking the collapse of empires and loosely-knit federations. It was thus at the end of the Roman Empire. We saw the pattern as the former Soviet Union collapsed (in the Baltic and East European states). We witnessed it again with the implosion of Yugoslaviaalthough, this time, the unfolding events were graced with a new term, 'ethnic cleansing' (as if we didn't already have 'genocide', 'massacre', 'annihilation', 'Holocaust', 'extermination' and 'liquidation'). State formation at the end of the British, French and Portuguese African empires in Africa were somewhat more on the Baltic scale and rarely attained the horror of former Yugoslavia. I am not here alluding to civil wars, such as that in Nigeria over the period 1967-1970. Rather, I am alluding specifically to the political expulsion/exclusion of 'strangers' or 'foreigners' (nationalist legislation often preferred the expression 'aliens') at the 
time of independence. There were two patterns-expunging the new states of their near neighbours, and putting pressure on residents from more far off places (India, Europe or the Middle East) to take out local citizenship, often under threat of the expropriation of their property. A very useful collection of case studies covering both patterns provided in Shack and Skinner (1979). The list below provides a flavour of the contributions to this important work:

- Peil (1979: 129) claims that the expression 'aliens' was not commonly used in Ghana until 1969, when it was applied to foreign Africans (previously called Wangara, Mossi, Lagosians or Ewe) under the terms of a new Compliance Order, enforcing the deportations of some 100,000 Africans.

- The fate of the Dahomeyans in other parts of Francophone Africa is discussed by Herscelle Sullivan Challenor (1979: 67-84).

- As for strangers from afar, the case of the Lebanese in Sierra Leone is discussed by Neil Leighton (1979: 85-104).

- The expulsion of Gaons and Asians in Uganda are discussed by Jessica Kuper (1979: 243-60), though the latter example has a much more extensive literature, which needs separate review.

- An interesting comparison between the expulsion of the Kenyan Luo workers and the Asian bourgeoisie from Uganda is provided by Ali Mazrui (1979: 261-88) who makes the point that in 1970 Obote expelled workers from a neighbouring country as part of his 'move to the left', whereas only two years later Asian businesspeople were expelled as part of Idi Amin 'economic war' mounted in favour of African capitalism. Though the ideas in this paper are underdeveloped, they provide a fertile starting point. Instead of looking at the social characteristics of the strangers, Mazrui points to the underdeveloped class formation on the part of the local population. 'Foreign' workers were expelled because the Ugandan working class was in the process of articulating its class interests; similarly, the nascent Ugandan bourgeoisie wanted to clear away its rivals in the interests of its own class formation.

\section{The Social Exclusion of Migrants in Globalized, Fragmented Cities}

The bulk of recent work on social inclusion/exclusion in Africa has focused on postcolonial/post-apartheid cities, notably the globalized African cities of Lagos, Nairobi and Johannesburg. In the early literature on the 'global city' only one, Johannesburg, was formally identified as a global city. Whether all three are global cities now and what we mean by 'fragmented' would need further elaboration elsewhere. Here, I would simply like to make a few points about these sites of social inclusion/exclusion:

- The most obvious point is that we have largely moved from the national levelstates in formation - to a cityscape, where local government is also likely to be a salient institutional player. 
- In each case there is clearly an abandonment of any effective means of policing inward migration and a significant collapse of comprehensive urban planning. Such controls were pretty nominal in Lagos for a long time, were slightly more enforced through the kipande certificate and urban zoning regulations in Nairobi, and were rather more regulated in the pass laws and police activity in Johannesburg. By 1994 this regulatory capacity had largely gone.

- The social actors in the landscape became local, national, regional and international—part of the escalating ramifications of 'super-diversity' discussed by Steve Vertovec (2007) though, arguably, this was a matter of degree rather than a shift in kind. There are also some salient differences. Lagos probably remained more regionalized in terms of inward migration, but return and oscillating transnational migration by Lagosians who had spent years abroad became an important part of its increasingly international profile. In Johannesburg and Nairobi, the international community became far more complex in its origins and class character. At the top of the structure are members of the transnational bureaucratic and business elites (of many ethnic origins) who share little of the sensibilities of the colonial/apartheid eras. At the bottom, ethnic enclaves became apparent in religious communities and the divisions of labour, trade and occupation.

- Within-city and near-city slums emerged with competing centres of authority and affiliation. In each case there are no significant mass public housing schemes or planned extensions to welfare benefits. In other words, in deference to the neo-liberal world order, there is no-or very little-attempt to make social citizenship work as a means of social inclusion.

- Instead, social inclusion has depended on market mechanisms, fitful government repression, limited local government planning (Johannesburg has been better here), charitable help and self-organization by migrants.

- At the political level, because there is poor take-up of, or access to, political citizenship, combined with near monopolistic forms of political competition, there is no serious attempt to mobilize the votes of the immigrants. This stands in notable contrast to cities like Boston, Chicago or New York where attracting immigrant votes was a significant element in election/re-election and helped greatly in the process of social inclusion.

In short, rather than review the studies of these African cities, I have simply drawn attention to some general features in the cityscape that may help to anchor our discussion.

\section{Concluding Note}

My broad purpose has been to provide a conceptual and historical overview of work on social inclusion/exclusion in Africa. Contemporary work often stresses citizenship, and legal and constitutional rights. I have emphasized earlier preoccupations, focusing particularly on the 'social' rather than the 'political'. I undertook comparison across the continent, developed a simple typology and drew 
on a sociological and anthropological sensibility. Africans have experienced stranger/host interactions before and the patterns that have emerged form part of the shared experience and, in some cases, habitus. It has to be admitted that my approach has slewed the argument in favour of scholars working in the late colonial or early post-colonial period, many of whom were expatriates or 'white Africans' born in southern Africa. To my knowledge all the quoted scholars were sympathetic to African aspirations, so we are not observing any obvious pro-colonial bias. Nonetheless, nowadays the overwhelming majority of trained social scientists are black Africans and it is likely that their concerns are rooted in the post-colonial period and in more overtly political issues, such as the competition for jobs and housing.

In a wider conceptual paper, not based on Africa, I delineated nine perspectives on social inclusion/exclusion (Cohen 2015). In the African case, the principal variations can be grouped in three types:

a. Swallowing (anthropophagic) societies - the agricultural, kingdom and refugee states, numbered 1, 2 and 3 above;

b. Parallel or alternating societies - the intermediate case, covering the ghetto and oscillating migrant labour, numbered 4 and 5 above;

c. Vomiting out (anthropoemic) societies-covering post-colonial state formation and the globalizing cities, numbered 6 and 7 above.

One needs to makes the obvious qualifications. These are typological categories, not ethnography. On the ground, reality is more complex; there is, naturally overlap and ambiguity. I should add that the anthropoemic type reflects the anger and heat of the moment. Not all expulsions are successful. They can be resisted and, as the Mexicans show so clearly in the case of the Rio Grande, the rivers of separation can be crossed again and again.

Acknowledgements An early version of this paper was first given to a conference on Reconsidering African Integration in a Fragmented Age, organized by the International Migration Institute (Oxford University), the African Centre for Migration \& Society (Witwatersrand University), and the Max Planck Institute for the Study of Religious and Ethnic Diversity (Göttingen) held at Fiume and River Place Country Estate, Hennops River, near Johannesburg, South Africa, 2-6 December 2013. I draw on the early part of my paper in an 'Afterword', which will be included in the published papers from this conference (forthcoming).

Open Access This article is distributed under the terms of the Creative Commons Attribution 4.0 International License (http://creativecommons.org/licenses/by/4.0/), which permits unrestricted use, distribution, and reproduction in any medium, provided you give appropriate credit to the original author(s) and the source, provide a link to the Creative Commons license, and indicate if changes were made.

\section{References}

Bakewell, Oliver. 2000. Repatriation and self-settled refugees in Zambia: Bringing solutions to the wrong problems. Journal of Refugee Studies 13 (4): 356-373. https://doi.org/10.1093/jrs/13.4.356. 
Barth, Fredrik. 1969. Ethnic groups and boundaries: the social organization of culture difference. Oslo: Universitetsforlaget.

Balandier, Georges. 1968. Daily life in the kingdom of the Kongo. London: Allen and Unwin.

Braverman, Harry. 1974. Labor and monopoly capital. New York: Free Press.

Challenor, Herscelle Sullivan. 1979. Strangers as colonial intermediaries: The dahomeyians in francophone Africa. In Strangers in African societies, ed. William A. Shack, and Elliot P. Skinner, 67-84. Berkeley: University of California Press.

Cobbing, Julian. 1988. The Mfecane as Alibi: Thoughts on Dithakong and Mbolompo. Journal of African History 29 (3): 487-519.

Cohen, Abner. 2004. Custom and politics in urban Africa: A study of Hausa migrants in Yoruba towns. London: Routledge.

Cohen, David W. 1972a. The historical tradition of Busoga. Oxford: Clarendon Press.

Cohen, Robin. 1972b. Class in Africa: Analytical problems and perspectives. In The socialist register, ed. R. Miliband, and J. Saville, 231-255. London: Merlin Press.

Cohen, Robin. 1974. Labour and Politics in Nigeria, 1945-71. London: Heinemann Educational Books.

Cohen, Robin. 1986. Endgame in South Africa: The changing structures and ideology of apartheid. London: James Currey.

Cohen, Robin (2015) Reconsidering social inclusion/exclusion in social theory: nine perspectives, three levels. Mondi Migranti: Rivista di studi e ricerche sulle migrazioni internazionali (Franco Angelli), Issue 1, pp 7-29.

Davis, J.Merle. 1933. Modern industry and the African. London: Macmillan.

Epstein, A.L. 1958. Politics in an urban African community. Manchester: Manchester University Press on behalf of The Rhodes-Livingstone Institute Northern Rhodesia.

Fage, John D. 1969. A history of West Africa. Cambridge: Cambridge University Press.

Frankenberg, Ronald (1957) Village on the border; a social study of religion, politics and football in a North Wales community. With an introduction by Max Gluckman. London: Cohen \& West.

Furnivall, J.S. 1948. Colonial policy and practice: A comparative study of Burma and Netherlands India. Cambridge: Cambridge University Press.

Gluckman, Max. 1963. Order and rebellion in tribal Africa. London: Cohen \& West.

Hailey, Lord Malcolm. 1938. An African survey: A study of problems arising in Africa south of the Sahara. Oxford: Oxford University Press.

Hamilton, Carolyn (ed.). 1995. The Mfecane aftermath: Reconstructive debates in southern African history. Pietermaritzburg: University of Natal Press.

Jingoes, Stimela Jason. 1975. A chief is a chief by the people. London: Oxford University Press.

Kapferer, Bruce. 1972. Strategy and transaction in an African factory: African workers and Indian management in a Zambian town. Manchester: Manchester University Press.

Khalanyane, Tankie K. 2012. Social closure in Lesotho: Forms and manifestations. Education 2 (7): 227-230. https://doi.org/10.5923/j.edu.20120207.02.

Kuper, Jessica. 1979. Goan and Asian in Uganda: An analysis of racial identity and cultural categories. In Strangers in African societies, ed. William A. Shack, and Elliot P. Skinner, 243-260. Berkeley: University of California Press.

Leighton, Neil. 1979. The political economy of a stranger population the Lebanese of Sierra Leone. In Strangers in African societies, ed. William A. Shack, and Elliot P. Skinner, 85-104. Berkeley: University of California Press.

Levi-Strauss, Claude. 1995. Tristes tropiques. Harmondsworth: Penguin.

Mayer, Philip. 1961. Townsmen or tribesmen: Conservatism and the process of urbanization in a South African city. Cape Town: Oxford University Press.

Mazrui, Ali. 1979. Casualties of an underdeveloped class structure; the expulsion of Luo workers and Asian bourgeoisie from Uganda. In Strangers in African societies, ed. William A. Shack, and Elliot P. Skinner, 262-278. Berkeley: University of California Press.

Mitchell, J.Clyde. 1969. Social networks in urban situations: Analysis of personal relationships in Central African towns. Manchester: Manchester University Press.

Mitchell, J.Clyde. 1974. Social networks. Annual Review of Anthropology 3: 279-299. https://doi.org/10. 1146/annurev.an.03.100174.001431.

Modo, I. V O. (1994) An anthropologist's view of ethnicity and ethnic conflicts in Africa. In Conference paper posted at http://www.ethnonet-africa.org/pubs/p95modo.htm.

Nyerere, Julius K. 1988. Ujamaa: The basis for African socialism. Nairobi: Oxford University Press.

Omer-Cooper, J.D. 1978. The Zulu aftermath. London: Longman. 
Paden, John. 1973. Religion and political culture in Kano. Berkeley: University of California Press.

Peil, Margaret. 1979. Host reactions: Aliens in Ghana. In Strangers in African societies, ed. William A. Shack, and Elliot P. Skinner, 123-140. Berkeley: University of California Press.

Sandbrook, Richard. 1975. Proletarians and African capitalism: The Kenyan case, 1960-1972. Cambridge: Cambridge University Press.

Sandbrook, Richard, and Robin Cohen (eds.). 1975. The development of an African working class: Studies in class formation and action. London: Longman Publishing Group.

Shack, William A., and Elliot P. Skinner. 1979. Strangers in African societies. Berkeley: University of California Press.

Turner, Victor. 1968. Schism and continuity in an African Society. Manchester: Manchester University Press.

Uhrmacher, Kevin and Mary Beth Sheridan (2016) The brutal toll of Boko Haram's attacks on civilians. Washington Post, 3 April.

Van Onselen, Charles. 1980. Chibaro: African mine labour in Southern Rhodesia, 1900-1933. London: Pluto Press.

Vertovec, Steven. 2007. Super-diversity and its implications. Ethnic and Racial Studies 30 (6): 1024-1054.

Webster, Eddie. 1985. Cast in a racial mould: Labour process and trade unionism in the foundries. Johannesburg: Ravan Press.

Young, Jock. 1999. The exclusive society: Social exclusion, crime and difference in late modernity. London: Sage.

Robin Cohen is Professor Emeritus of Development Studies and Senior Research Fellow, Kellogg College, University of Oxford. He was born in South Africa and studied politics and history at the University of the Witwatersrand before leaving for the UK. He has worked also in Nigeria and Trinidad and was Dean of Humanities at the University of Cape Town (2001-3). His books include Labour and politics in Nigeria (1974, rev. 1982), Endgame in South Africa? (1986), The new helots: migrants in the international division of labour (1987, 1993, 2003), Contested domains: debates in international labour studies (1991), Frontiers of identity: the British and the others (1994), Global diasporas: an introduction (1997, rev. 2008), Global sociology (co-author, 2000, rev. 2007, rev. 2013), Migration and its enemies (2006) and Encountering difference (co-author, 2016). He has edited or co-edited 21 further volumes. 